\title{
Characterisation and correlation of Tertiary seismostratigraphic units in the Roer Valley Graben
}

\author{
J.W. Verbeek ${ }^{1,3}$, C.S. de Leeuw ${ }^{2}$, N. Parker ${ }^{1}$ \& Th.E.Wong ${ }^{1}$
}

1 Netherlands Institute of Applied Geoscience TNO - National Geological Survey, Department of Geo-Energy, P. O. Box 80015, 3508 TA Utrecht, the Netherlands.

2 Elf Petroland, P.O. Box 93280, 2509 AGThe Hague, the Netherlands.

3 Corresponding author: j.verbeek@nitg.tno.nl

Manuscript received: September 2000; accepted: January 2002

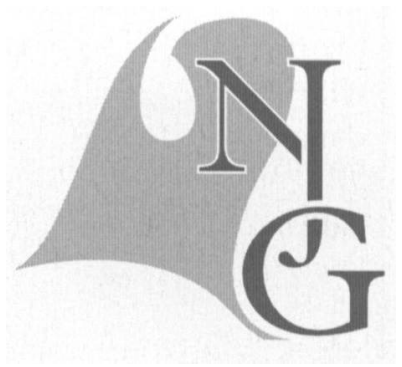

\begin{abstract}
Within the Cenozoic sedimentary section of the Roer Valley Graben ten seismostratigraphic units have been identified. They are closely related to the lithological framework which makes it possible to recognize them also on well logs in this region. The Lower Tertiary seismic units, representing mainly marine sediments, have a uniform development that can be correlated over large distances into the German part of the Roer Valley Graben. The marine to continental Upper Tertiary and Quaternary seismic units display a more complex development due to lateral facies changes (including prograding delta systems) and rift tectonics.
\end{abstract}

Key words: Tertiary, RoerValley Graben, stratigraphy, the Netherlands

\section{Introduction}

In the Roer Valley Graben (Figs 1,2) a maximum of $1800 \mathrm{~m}$ of Tertiary sediments have been accumulated. Although some papers deal with the Tertiary history of the Roer Valley Graben (Zagwijn, 1989; Geluk, 1990; Geluk et al., 1994; Zijerveld et al., 1994), no publications exist on the identification and characterization of the individual Tertiary lithological units in this area. In contrast, Demyttenaere \& Laga (1988) and Demyttenaere (1989) published detailed studies of the Belgian part. Recently, De Batist \& Versteeg (1999) published a study on the seismic stratigraphy of the Mesozoic and Cenozoic sediments of the Campine Block in northern Belgium.

The present study is a first attempt to increase the understanding of the spatial distribution of the various Tertiary lithological units in terms of log correlations and seismic interpretations. This research is based on both seismic and well data. In this context about $2000 \mathrm{~km}$ of $2 \mathrm{D}$ seismic lines and $400 \mathrm{~km}^{2}$ 3D seismics have been interpreted and linked to boreholes. The study has been carried out in the framework of the mapping program to produce the Geological Atlas of the subsurface of the Netherlands (scale 1:250 000), Map Sheets XIII and XIV (TNO-NITG, 2001). In this study we follow the standard lithostratigraphic subdivision of the Tertiary (Fig. 3) as outlined in Van Adrichem Boogaert \& Kouwe (1997).

\section{Geological setting}

The Roer Valley Graben is a northwest trending branch of the Rhine Graben system (Fig. 1). As indicated in Fig. 2, the Roer Valley Graben is separated in the south from the Campine Block by the complex Feldbiss and in the north from the Peel Block and Maasbommel High by the even more complex Peel Boundary Fault (Ziegler, 1994; Geluk et al., 1994). The graben developed upon former sedimentary 

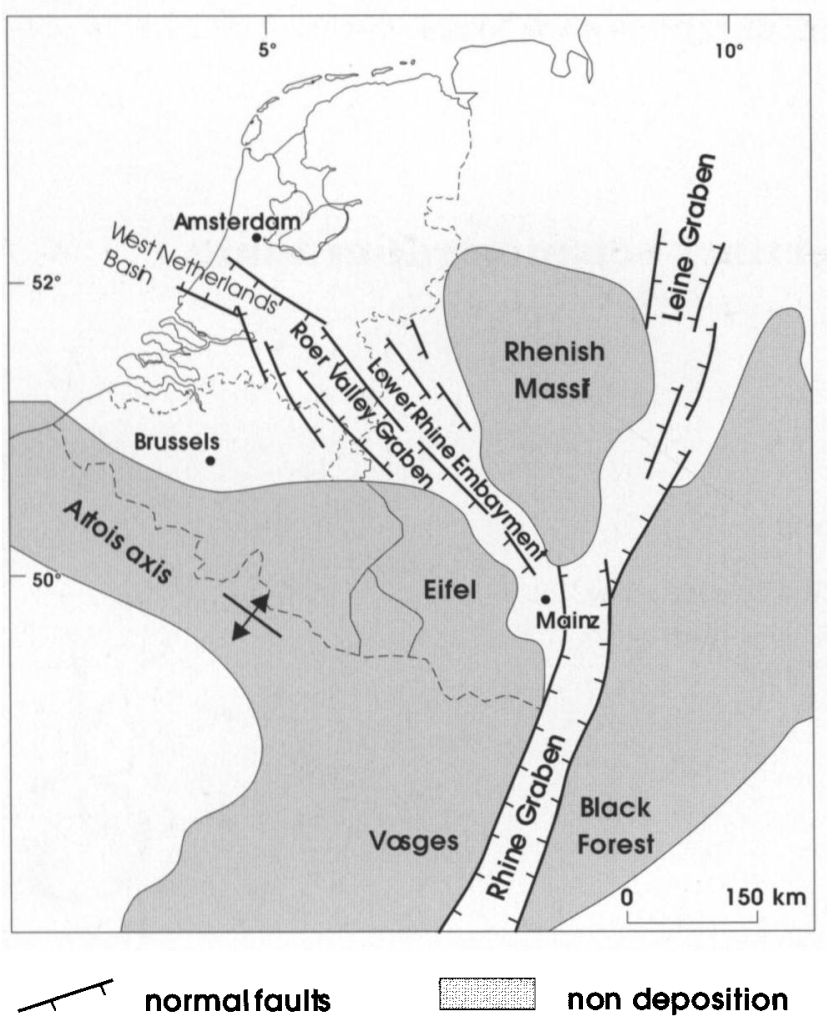

Fig. 1. The Cenozoic Graben system in north-western Europe (after Geluk, 1990).

basins of Carboniferous, Triassic to Early Jurassic, and Late Jurassic age. Differential subsidence of the Roer Valley Graben started in the Late Oligocene (Geluk et al., 1994; Zijerveld et al., 1994).

\section{Geological history}

In the Tertiary several phases of tectonic activity can be recognized starting with a period of inversion (Laramide phase; see Fig. 3) at the end of the Early Paleocene.

This phase only had a limited effect in the Roer Valley Graben, and only resulted in a hiatus in the succession (Gras \& Geluk, 1999). The extensive calcareous sedimentation, which was so typical for the Late Cretaceous and earliest Tertiary, came to an abrupt end. During the Late Paleocene and Early Eocene, marine sediments were deposited. In the Late Eocene, the Pyrenean tectonic phase (Fig.3) caused uplift in a large area in north-eastern Belgium (De Moulin, 1995; Vandenberghe et al., 1998) and southeastern Netherlands (Letsch \& Sissingh, 1983; Van Adrichem Boogaert \& Kouwe, 1997). The ensuing erosion removed most of the Eocene and, in the south-eastern part of the Roer Valley Graben, also most of the Upper Paleocene sediments. In the earliest Oligocene, sedimentation resumed in this area. At the beginning of the Late Oligocene, the Roer Valley
Graben fault system was reactivated (Zagwijn, 1989; Geluk et al., 1994), which caused large differences in the thickness of the Upper Oligocene and younger formations in the graben and the flanking horst blocks. Movements along this fault system still occurs, as demonstrated by terrain steps and scarps, and fault-influenced drainage patterns (Van den Berg et al., 1994) as well as the earthquakes in this region (Ahorner, 1994; Camelbeek et al., 1994). At the Oligocene-Miocene transition, regional uplift occurred, related to the Savian phase (Fig. 3). This, in conjunction with a major lowstand, culminated in erosion during the Early Miocene. Resumed marine sedimentation in the Early Miocene was initially confined to the Roer Valley Graben, but rapidly extended to the more elevated, flanking blocks (Zagwijn, 1989). To the Southeast, in the Lower Rhine Embayment, fluvial sedimentation continued in the Miocene (Ville and Inden fms.). In the deltaic transitional area towards the marine realm lying further to the west, marine marshes with mangroves developed, where widespread peat formation took place (Zagwijn \& Hager, 1987). This resulted in the deposition of very thick sequences of brown coal (e.g. the Morken and Frimmersdorf seams, which are tongues of a massive brown coal section; see Fig. 5). During low stands, the continental deposits built out over the marine depositional area much further to the west (e.g. the Heksenberg Member of the Ville Formation). The Late Miocene and Pliocene were characterized by a significant regression. The resulting sand and gravel deposits of the Kieseloolite Formation were deposited in a protruding delta of a precursor of the Rhine, with braided and meandering streams, building out far into the Roer Valley Graben, also covering the Venlo Block. Mainly in the Pliocene, this fluvial area was replaced by lakes, where clay and peat accumulated (NITG-TNO, 1999).

\section{Seismic units}

In Fig. 4, an E-W seismic section through the Roer Valley Graben is presented in which 10 seismic units have been identified. These seismic units are closely linked to the lithological framework (see Fig. 5). In general, the Paleocene through Lower Miocene seismic units are transparent with a minimum of internal reflection, which reflect the overall dominance of clay and silt without significant sandy intercalations.

The units above the Lower Miocene unit show strong internal reflection indicating mainly sandy and carbonaceous sediments with intercalations of finegrained sediments. An overview of the characteristics of the seismic units is given in Table 1 . 
Table 1. Overview of characteristics of the seismostratigraphic units and their relation to litho- and chronostratigraphy (modified after TNO-NITG, 2001).

\begin{tabular}{|c|c|c|c|c|c|c|c|c|}
\hline \multirow[t]{2}{*}{ Seismic unit } & \multirow{2}{*}{$\begin{array}{l}\text { chrono- } \\
\text { stratigraphy }\end{array}$} & \multirow{2}{*}{$\begin{array}{l}\text { Litho- } \\
\text { stratigraphy }\end{array}$} & \multirow{2}{*}{$\begin{array}{l}\text { sedimentary } \\
\text { facies }\end{array}$} & \multicolumn{5}{|c|}{ seismic facies } \\
\hline & & & & amplitudes & continuity & frequency & $\begin{array}{l}\text { lower } \\
\text { boundary }\end{array}$ & $\begin{array}{l}\text { upper } \\
\text { boundary }\end{array}$ \\
\hline $\mathrm{X}$ & Quaternary & diverse & $\begin{array}{l}\text { fluvial- } \\
\text { periglacial }\end{array}$ & high & limited & high & conform & \\
\hline IX & Pliocene & $\begin{array}{l}\text { Oosterhout/ } \\
\text { Kieseloolite } \\
\text { Formation }\end{array}$ & $\begin{array}{l}\text { marine- } \\
\text { deltaic- } \\
\text { fluvial }\end{array}$ & high & $\begin{array}{l}\text { limited, } \\
\text { clinoforms } \\
\text { shingled to } \\
\text { complex } \\
\text { sigmoid }\end{array}$ & high & $\begin{array}{l}\text { conform, } \\
\text { downlap, }\end{array}$ & $\begin{array}{l}\text { conform, } \\
\text { toplap, } \\
\text { incision }\end{array}$ \\
\hline VIII & $\begin{array}{l}\text { Late } \\
\text { Miocene }\end{array}$ & $\begin{array}{l}\text { (upper) } \\
\text { Breda } \\
\text { Formation }\end{array}$ & $\begin{array}{l}\text { marine- } \\
\text { deltaic }\end{array}$ & $\begin{array}{l}\text { low to } \\
\text { medium }\end{array}$ & $\begin{array}{l}\text { limited, } \\
\text { clinoforms } \\
\text { shingled }\end{array}$ & high & $\begin{array}{l}\text { conform, } \\
\text { onlap, } \\
\text { downlap }\end{array}$ & $\begin{array}{l}\text { conform, } \\
\text { toplap, } \\
\text { incision }\end{array}$ \\
\hline VII & $\begin{array}{l}\text { Middle } \\
\text { Miocene }\end{array}$ & $\begin{array}{l}\text { (middle) } \\
\text { Breda } \\
\text { Formation }\end{array}$ & $\begin{array}{l}\text { marine- } \\
\text { deltaic }\end{array}$ & medium & $\begin{array}{l}\text { limited, } \\
\text { clinoforms } \\
\text { shingled }\end{array}$ & high & $\begin{array}{l}\text { conform, } \\
\text { onlap, } \\
\text { downlap }\end{array}$ & $\begin{array}{l}\text { conform, } \\
\text { toplap }\end{array}$ \\
\hline VI & $\begin{array}{l}\text { Early } \\
\text { Miocene }\end{array}$ & $\begin{array}{l}\text { (lower) } \\
\text { Breda } \\
\text { Formation }\end{array}$ & marine & high & large & high & conform & conform \\
\hline $\mathrm{V}$ & $\begin{array}{l}\text { Late } \\
\text { Oligocene }\end{array}$ & $\begin{array}{l}\text { Veldhoven } \\
\text { Formation }\end{array}$ & marine & low & large & low & conform & $\begin{array}{l}\text { conform, } \\
\text { incision }\end{array}$ \\
\hline IV & $\begin{array}{l}\text { Early } \\
\text { Oligocene }\end{array}$ & $\begin{array}{l}\text { Rupel } \\
\text { Formation }\end{array}$ & marine & low & very large & low & conform & conform \\
\hline III & Eocene & $\begin{array}{l}\text { Dongen } \\
\text { Formation }\end{array}$ & marine & $\begin{array}{l}\text { high (upper } \\
\text { part) and low } \\
\text { (lower part) }\end{array}$ & $\begin{array}{l}\text { limited } \\
\text { (upper } \\
\text { part); large } \\
\text { (lower part) }\end{array}$ & $\begin{array}{l}\text { high (upper } \\
\text { part); low } \\
\text { (lower part) }\end{array}$ & conform & $\begin{array}{l}\text { conform, } \\
\text { incision, } \\
\text { truncation }\end{array}$ \\
\hline II & $\begin{array}{l}\text { Late } \\
\text { Paleocene }\end{array}$ & $\begin{array}{l}\text { Landen } \\
\text { Formation }\end{array}$ & marine & low & large & low & conform & $\begin{array}{l}\text { conform } \\
\text { slightly } \\
\text { truncated }\end{array}$ \\
\hline I & $\begin{array}{l}\text { Early } \\
\text { Paleocene }\end{array}$ & $\begin{array}{l}\text { Houthem } \\
\text { Formation }\end{array}$ & marine & high & limited & high & conform & $\begin{array}{l}\text { conform } \\
\text { slightly } \\
\text { truncated }\end{array}$ \\
\hline & Mesozoic & & & & & & & $\begin{array}{l}\text { conform, } \\
\text { truncation }\end{array}$ \\
\hline
\end{tabular}

Unit I comprises the Houthem Formation, which is of Early Paleocene age, and consists of marine limestone and marls. In the northwest of the Roer Valley Graben, this unit has been eroded. Generally the unit is too thin to show any internal reflection.

Unit II is the lowest unit of the Tertiary clastic sequence; it consists of Upper Paleocene, marine sediments of the Landen Formation. This rather uniform and transparent unit is present in the entire Roer Val- ley Graben. In the Southeast and central part of this area the unit is thicker than elsewhere in the graben. Here, one or two distinct reflectors may be visible. The lower boundary is a rather continuous high-amplitude reflector, that either conformably overlays the top of truncated Mesozoic or unit I deposits.

Unit III represents the Eocene, marine sediments of the Dongen Formation. Unit III conformably covers the Paleocene unit II. The lower boundary some- 


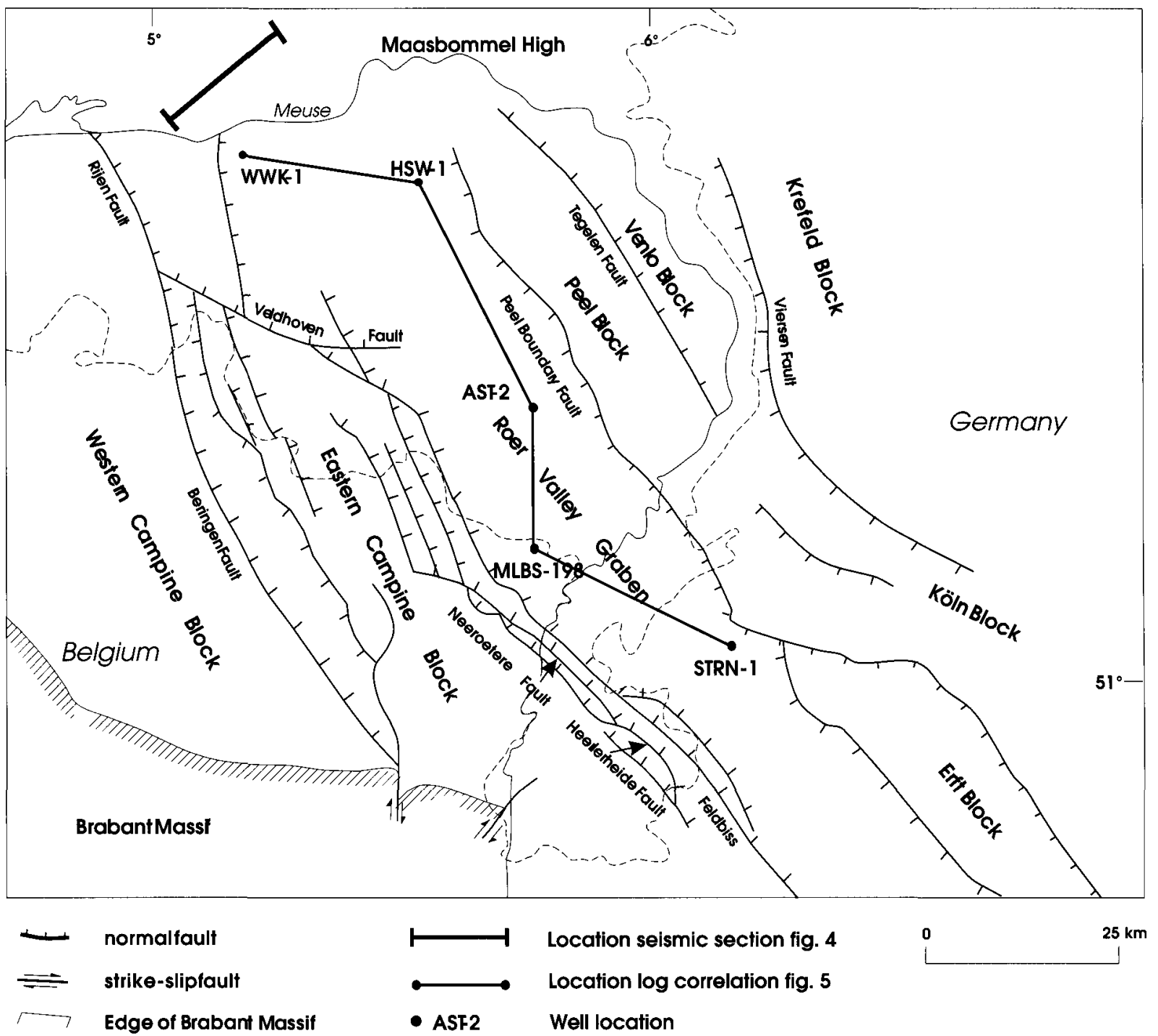

Fig. 2. Main structural elements around the Roer Valley Graben, showing locations of seismic profile of Fig. 4 and correlation panel of Fig. 5. WWK-1 = Waalwijk-1, HSW-1 = Heeswijk-1, AST-2= Asten-2, MLBS-198= Molenbeersel-198 and STRN-1= Straeten-1 (modified after Geluk et al., 1994).

times consists of two distinct reflectors, but generally, it is one broad reflector. In the south-eastern part of the Roer Valley Graben, the unit is absent due to erosion. Generally, the unit is rather thin and almost transparent except in the western part of the area where it is much thicker. Here the transparent lower part is covered by a number of distinct reflectors. In the west of the Roer Valley Graben, the upper part of the unit is severely truncated. Across the faults, the thickness of unit III can significantly change as a result of differential uplift. Locally, even distinct reverse faulting is observed in this unit. This faulting is indicative of a compressional phase and uplift in the southern Netherlands.

Unit IV, which comprises the Lower Oligocene marine sediments of the Rupel Formation, is continuous without much variation in thickness. It has a more or less distinct reflector in the centre. This observation of the geometry is well in accordance with Hager et al. (1998), who envisaged this geometrical characterization for a much larger area. In the major part of the Roer Valley Graben, the unit unconformably overlies the units II in the Southeast and unit III in the rest of the Roer Valley Graben. The lower boundary is characterized by a low-amplitude reflector. In the western part of the area the facies changes are more distinct and because of the truncation of the underlying Eocene sediments, the lower boundary is well recognizable by a high amplitude reflector in the 3D surveys, but indistinct in the $2 \mathrm{D}$ profiles. The upper boundary generally is a conformable, but rather lowamplitude reflector.

The Upper Oligocene, marine sediments of the Veldhoven Formation are represented in unit $\mathrm{V}$, which varies in thickness and seismic expression. In the Southeast of the Roer Valley Graben, unit V is thick 
and transparent, with a double reflector in the centre. This internal reflector is more or less continuous throughout the entire area. Towards the west, the unit becomes thinner and it may change in thickness across the faults. These changes are generally opposite to changes in the thickness of the Eocene sedimentary sequence of unit III. In the centre of the Roer Valley Graben, unit $\mathrm{V}$ shows an irregular pattern of reflectors. The lower boundary is a generally well recognizable reflector with the unit $\mathrm{V}$ conformably overlying unit IV. In areas where the thickness of unit $\mathrm{V}$ strongly changes, the lower boundary is characterized by onlap. The changes in thickness are the result of differential fault movements in the Late Eocene related to renewed extension in both the Roer Valley Graben and Lower Rhine Embayment.

Unit VI comprises the marine sediments of the lower part of the Breda Formation, which is correlated with the Early Miocene. The unit is characterized by an irregular lower boundary consisting of discontinuous high-amplitude reflectors. It overlies unit $\mathrm{V}$ conformably, sometimes some weak truncation is observed. Unit VI generally shows two regularly spaced high-amplitude reflectors. Only in the centre of the area the amount of reflectors increases. Towards the west of the Roer Valley Graben, these two reflectors become less distinct. The upper boundary is conformable. The thickness of unit VI is rather constant with exception of the centre of the graben where the unit is thicker.

Unit VII comprises the Middle Miocene sediments of the middle part of the Breda Formation. The marine to deltaic sediments of this unit are especially thick in the east with rather distinct reflectors at base and top, and it shows an irregular pattern of subparallel reflectors. In the centre of the graben, the unit shows shingled clinoforms indicating a prograding sedimentation. The lower boundary is characterized by downlap over the Lower Miocene unit and onlap against the Eastern Campine Block. In this part of the graben, the unit shows its maximum thickness. Towards the west, the thickness strongly decreases and in the westernmost part of the graben, the unit disappears completely. Here, the unit also shows a pattern of short subparallel reflectors. The upper boundary is an irregular pattern of reflectors probably indicating erosion. The unit includes part of the Miocene terrestrial sediments of the Ville Formation (Heksenberg Member), which are only present in the south-eastern part of the Roer Valley Graben. This seismically transparent member, bounded at the top by an almost conform reflector, is recognized at the base of unit VII directly overlying unit VI.

Unit VIII consists of the Upper Miocene (marine-

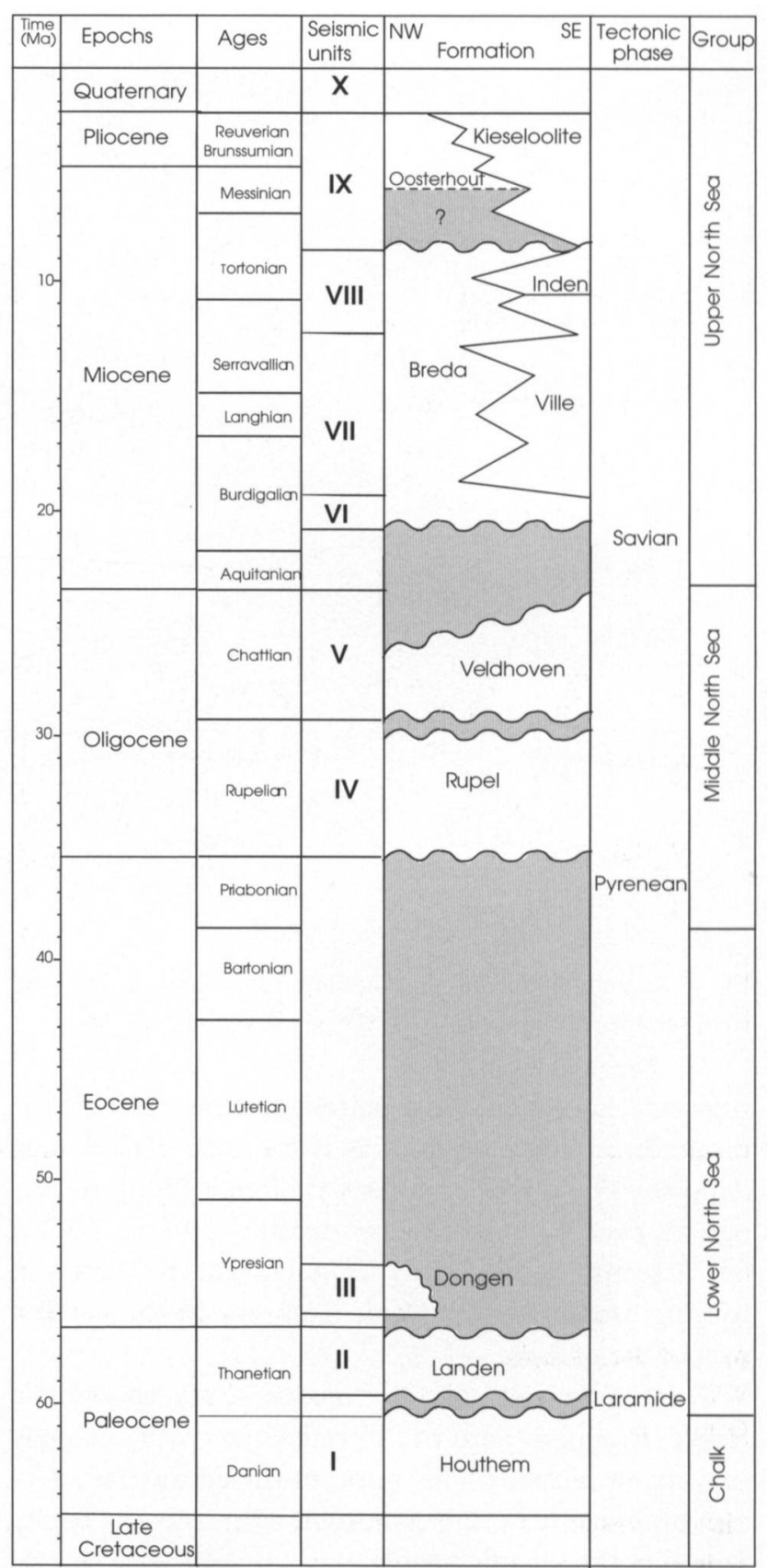

Fig. 3. Tertiary stratigraphy of the Roer Valley Graben.

deltaic) section corresponding to the upper part of the Breda Formation and other complementary sediments (Fig. 3). It shows the same pattern as unit VII: an aggradational pattern in the east and west of the graben and the maximum thickness in the centre with shingled clinoforms. In the western part some subunits occur, which may indicate different directions of sediment transport. Unit IX comprises Upper Miocene and Pliocene sediments in the south-eastern part of the area. In the north-western part however, only Pliocene sediments make up this unit (Fig. 3). In the centre of the Roer Valley Graben, unit IX shows an irregular pattern of more or less parallel reflectors, whereas towards the west the pattern consists of large 


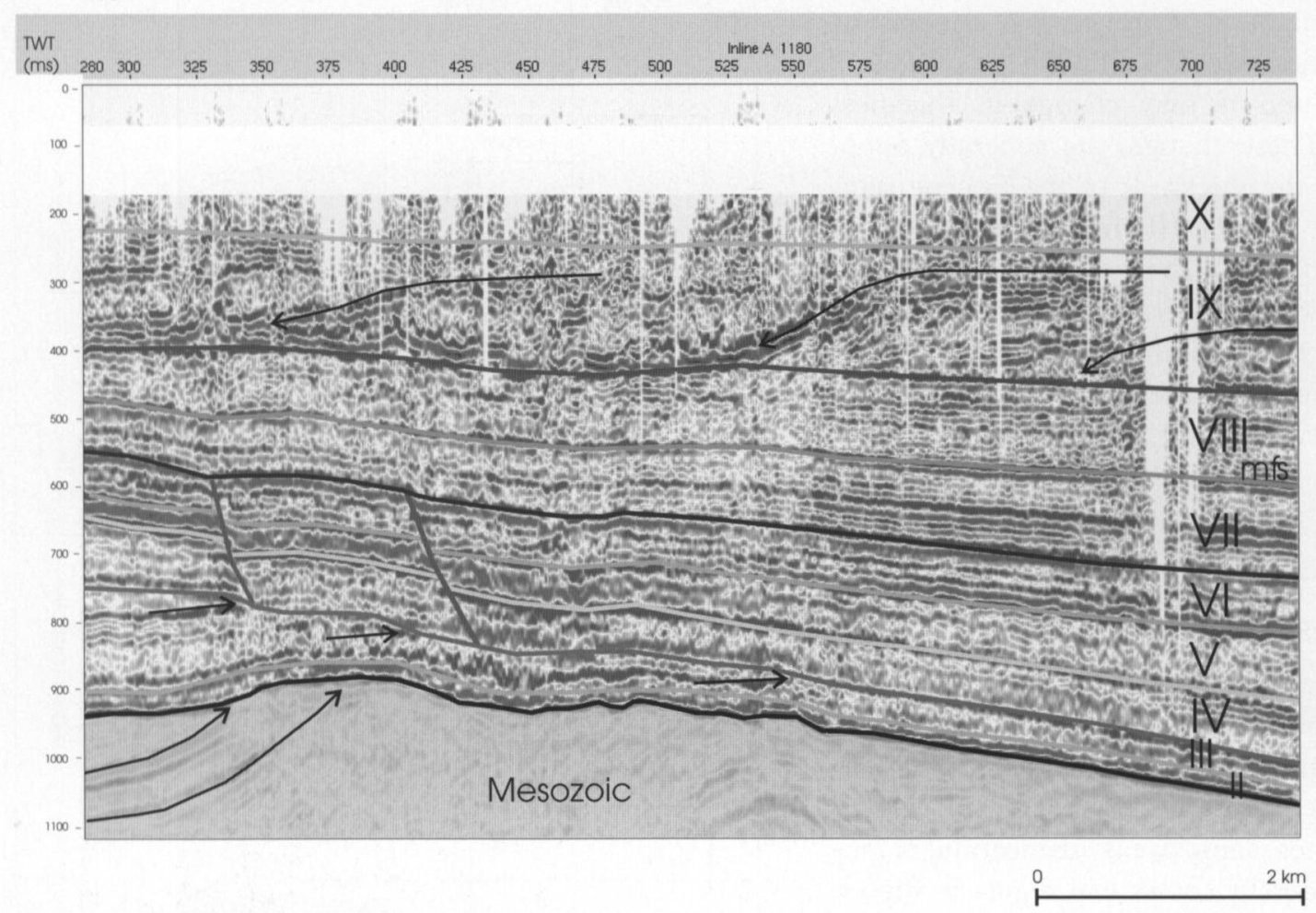

Fig. 4. Seismic section through the Roer Valley Graben, showing various Tertiary seismo stratigraphic units. The location of the section is shown in Fig. 2 (modified after TNO-NITG, 2001).

sigmoid clinoforms. This pattern is characteristic for prograding sedimentation, as is the case with deltaic deposits. The upper boundary is often difficult to recognize, because of its shallow depth $(<200 \mathrm{~ms}$ TWT), but it seems to be slightly irregular with reflectors of varying amplitude. The unit is absent in the eastern part of the graben.

Unit X consists of Quaternary strata showing a rather irregular pattern of reflectors with strongly varying amplitudes. This uppermost sedimentary section of fluvial to periglacial origin often is badly represented in the seismic profiles.

\section{Correlation and discussion}

The Tertiary sedimentation history of the Roer Valley Graben appears to be strongly governed by sea level movements, mild inversion tectonics and differential subsidence.

The major Tertiary lithostratigraphic units also correlate with seismo-stratigraphic units, which makes it possible to seismically map these units. Especially, the Paleogene units have a uniform development that can be recognized over wide distances from the German part of the Roer Valley Graben towards the NW.

The Neogene section however is more complicated due to lateral facies changes and rift tectonics. In the German part of the Roer Valley Graben, the Miocene section consists of marine and non-marine sediments, and the Pliocene is probably completely non-marine. In the eastern part of the Dutch Roer Valley Graben, the Miocene comprises three units, two of which being marine and one partly non-marine to partly marine. In the well logs, this succession is also recognizable (Fig. 5). The Lower Miocene is characterized by rather high gamma-ray readings with a distinct positive excursion in the upper part. The other two units show much lower gamma-ray values, decreasing upwards. This sequence is also observed in the Belgian borehole Molenbeersel198.

The section is correlated with the German borehole Straeten-1. This correlation focussed on the Miocene interpretation of Fabian (1958). In the Straeten-1 well, the high gamma-ray values of the Lower Miocene are well recognizable between 733 and $640 \mathrm{~m}$ (Fig. 5). Flooding surfaces have been identified at 560 and $464 \mathrm{~m}$ represented by respectively a flint layer and a shell bed in combination with high gamma ray readings. It is concluded, that the interval between 640 and $560 \mathrm{~m}$ correlates with the deltaic Miocene of the Dutch Roer Valley Graben. This interval includes the peat layers Morken and Frimmersdorf. The intervals from 560 through $464 \mathrm{~m}$ and from $464 \mathrm{~m}$ through $327 \mathrm{~m}$ correlate with respec- 


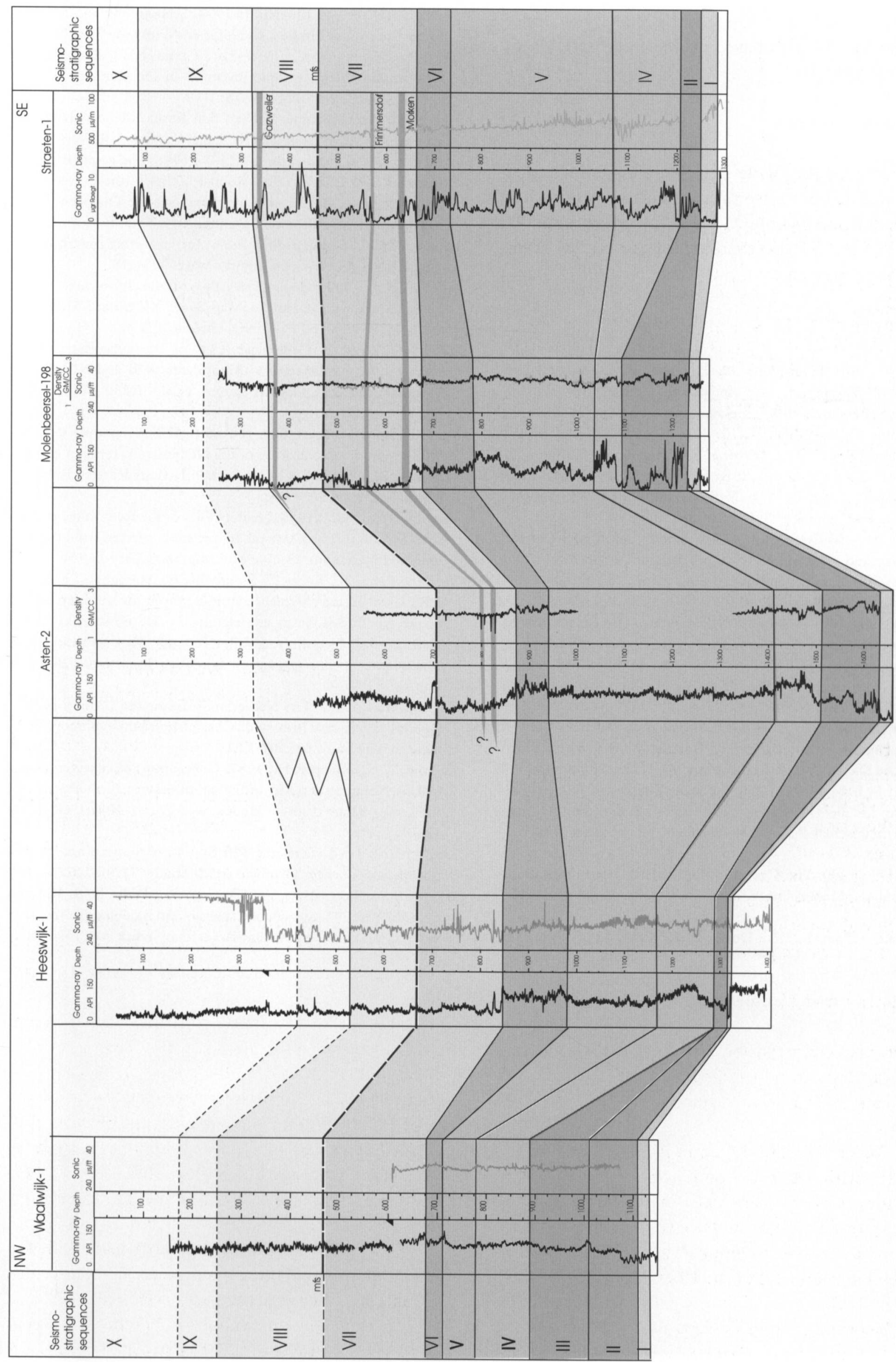

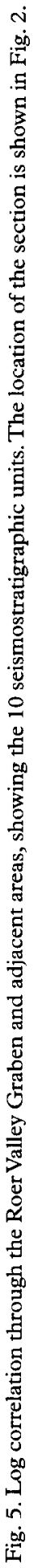


tively the Middle and Upper Miocene. This upper boundary at $327 \mathrm{~m}$ is based on the interpretation of Fabian (1958).

\section{Acknowledgements}

The authors thank Clyde Petroleum Exploratie B.V. for the permission to use relevant Tertiary subsurface data for this publication. M.C. Geluk (Assen) and W. Ricken (Köln) are also thanked for the critical reading of this manuscript.

\section{References}

Ahorner, L., 1994. Fault-plane solutions and source parameters of the 1992 Roermond, the Netherlands, mainshock and its stronger aftershocks from regional seismic data. Geologie en Mijnbouw 73: 199-214.

Camelbeek, T., Van Eck, T., Pelzing, R., Ahorner, L., Loohuis, J., Haak, H.W., Hoang-Trong, P. \&. Hollnack, D., 1994. The 1992 Roermond earthquake, the Netherlands, and its aftershocks. Geologie en Mijnbouw 73: 181-197.

De Batist, M. \& Versteeg, W.H., 1999. Seismic stratigraphy of the Mesozoic and Cenozoic in Northern Belgium: main results of a high-resolution reflection seismic survey along rivers and canals. Geologie en Mijnbouw 77: 17-37.

De Moulin, A., 1995. Les surfaces d'érosion méso-cénozoïques en Ardenne-Eifel. Bull. Soc. Geol. France 166, 5: 573-585.

Demyttenaere, R., 1989. The post-Paleozoic geological history of north-eastern Belgium. Med. Kon. Acad. Wetensch. Lett. Sch. Kunst Belg. 51: 51-81.

Demyttenaere, R. \& Laga, P., 1988. Breuken en isohypsenkaarten van het Belgische gedeelte van de Roerdal Slenk. Belgische Geologische Dienst Professional Paper 1988/4, 234: 20 pp.

Fabian, H.J., 1958. Die Aufschlußbohrung Straeten-1 und ihre Bedeutung für die Gliederung des Tertiärs im südlichen Teil der Niederrheinischen Bucht. Fortschr.Geol. Rheinlnd. u. Westf., 1 u. 2: 11-28.

Geluk, M.C., 1990. The Cenozoic Roer Valley Graben, Southern Netherlands. Mededelingen Rijks Geologische Dienst 44-4: 6572.

Geluk, M.C., Duin, E.J.Th., Dusar, M., Rijkers, R.H.B., Van den
Berg, M.W. \& Van Rooijen, P.,1994. Stratigraphy and tectonics of the Roer Valley Graben. Geologie en Mijnbouw 73: 129-141.

Gras, R. \& Geluk, M.C., 1999. Late Cretaceous - Early Tertiary sedimentation and tectonic inversion in the southern Netherlands. Geologie en Mijnbouw 78: 1-19.

Hager, H., Vandenberghe, N., Van den Bosch, M., Abraham, M., Von der Hocht, F., Rescher, K., Laga, P., Nickel, E., Verstrealen, A., Leroi, S. \& Van Leeuwen, R.J.W., 1998. The geometry of the Rupelian and Chattian depositional bodies in the Lower Rhine district and its border area: implications for Oligocene lithostratigraphy. Bull. Geol. Soc. Denmark 45: 53-62.

Letsch, W.J. \& Sissingh, W., 1983. Tertiary stratigraphy of the Netherlands. Geologie en Mijnbouw 62: 305-318.

NITG-TNO, 1999. Geological Atlas of the subsurface of the Netherlands, Explanation to Map Sheet XV Sittard-Maastricht (scale 1:250 000), NITG-TNO, Utrecht: $127 \mathrm{pp}$.

TNO-NITG, 2001. Geological Atlas of the subsurface of the Netherlands, Explanation to Map Sheets XIII and XIV, BredaValkenswaard and Oss-Roermond (scale 1:250 000), TNONITG, Utrecht: 149 pp.

Van Adrichem Boogaert, H.A. \& Kouwe, W.F.P. (compilers), 1997. Stratigraphic nomenclature of the Netherlands, revision and update by RGD and NOGEPA. Section I, Mededelingen Rijks Geologische Dienst 50: $39 \mathrm{pp}$

Van den Berg, M.W., 1994. Neotectonics of the Roer Valley rift system. Style and rate of crustal deformation inferred from syn-tectonic sedimentation. Geologie en Mijnbouw 73: 143-156.

Vandenberghe, N., Laga, P., Steurbaut, E., Hardenbol, J. \& Vail, P.R., 1998. Tertiary sequence stratigraphy at the southern border of the North Sea Basin in Belgium. In: De Graciansky, P.-C., Hardenbol, J., Jacquin, T. \& Vail, P.R. (eds): Mesozoic and Cenozoic sequence stratigraphy of European basins, SEPM Spec. Pub. 60: 119-164.

Zagwijn, W.H., 1989. The Netherlands during the Tertiary and the Quaternary: A case history of Coastal Lowland evolution. Geologie en Mijnbouw 68: 107-120.

Zagwijn, W.H. \& Hager, H., 1987. Correlations of continental and marine Neogene deposits in the south-eastern Netherlands and the Lower-Rhine district. Meded. Werkg. Tert. Kwart. Geol. 24: 59-78.

Ziegler, P.A., 1994. Cenozoic Rift System of western and central Europe: an overview. Geologie en Mijnbouw 73: 99-127.

Zijerveld, L., Stephenson, R., Cloetingh, S., Duin, E. \&. Van den Berg, M.W.,1992. Subsidence analysis and modelling of the Roer Valley Graben (SE Netherlands). Tectonophysics 208: 159-171. 